\title{
Autophagy counteracts instantaneous cell death during seasonal senescence of the fine roots and leaves in Populus trichocarpa

\author{
Natalia Wojciechowska ${ }^{1 *}$, Katarzyna Marzec-Schmidt ${ }^{1}$ Ewa M Kalemba², Aleksandra Zarzyńska-Nowak²,
} Andrzej M Jagodziński and Agnieszka Bagniewska-Zadworna ${ }^{1 *}$

\begin{abstract}
Background: Senescence, despite its destructive character, is a process that is precisely-regulated. The control of senescence is required to achieve remobilization of resources, a principle aspect of senescence. Remobilization allows plants to recapture valuable resources that would otherwise be lost to the environment with the senescing organ. Autophagy is one of the critical processes that is switched on during senescence. This evolutionarily conserved process plays dual, antagonistic roles. On the one hand, it counteracts instantaneous cell death and allows the process of remobilization to be set in motion, while on the other hand, it participates in the degradation of cellular components. Autophagy has been demonstrated to occur in many plant species during the senescence of leaves and flower petals. Little is known, however, about the senescence process in other ephemeral organs, such as fine roots, whose lifespan is also relatively short. We hypothesized that, like the case of seasonal leaf senescence, autophagy also plays a role in the senescence of fine roots, and that both processes are synchronized in their timing.

Results: We evaluated which morphological and cytological symptoms are universal or unique in the senescence of fine roots and leaves. The results of our study confirmed that autophagy plays a key role in the senescence of fine roots, and is associated also with the process of cellular components degradation. In both organs, structures related to autophagy were observed, such as autophagic bodies and autophagosomes. The role of autophagy in the senescence of these plant organs was further confirmed by an analysis of ATG gene expression and protein detection.

Conclusions: The present study is the first one to examine molecular mechanisms associated with the senescence of fine roots, and provide evidence that can be used to determine whether senescence of fine roots can be treated as another example of developmentally programmed cell death (dPCD). Our results indicate that there is a strong similarity between the senescence of fine roots and other ephemeral organs, suggesting that this process occurs by the same autophagy-related mechanisms in all plant ephemeral organs.
\end{abstract}

Keywords: Autophagy, ATG genes, ATG8 protein, Senescence, Leaves, Fine roots

\section{Background}

Senescence, as the final, inevitable stage of development before death, can occur in a select group of cells, tissues, organs, or even an entire plant. Seasonal senescence of organs is an adaptation that allows plants to adapt to a yearly change in environmental conditions. Regardless of the reason, senescence is a precisely regulated process

\footnotetext{
* Correspondence: natalia.wojciechowska@amu.edu.pl; agabag@amu.edu.pl 'Department of General Botany, Institute of Experimental Biology, Faculty of Biology, Adam Mickiewicz University, Umultowska 89, 61-614 Poznań, Poland Full list of author information is available at the end of the article
}

that follows well-defined steps, clearly reflected by distinct physiological, cytological, and transcriptomic events $[1,2]$. The precise control of senescence is necessary to allow the process of remobilization to occur, which is the main goal of prolonged senescence instead of rapid death [3]. During senescence, the degradation of cellular components is accelerated. The remobilization process allows those degraded components, that are still valuable for plants, to be transformed into forms that can be transported in the phloem and relocated to other parts of the plant e.g. to developing seeds or other

(c) The Author(s). 2018 Open Access This article is distributed under the terms of the Creative Commons Attribution 4.0 International License (http://creativecommons.org/licenses/by/4.0/), which permits unrestricted use, distribution, and 
storage organs [4-8]. There is also a body of evidence which demonstrates that autophagy plays a significant role in nutrient recycling during the senescence of plant organs [9-12].

Autophagy is an evolutionarily conserved, intracellular pathway in eukaryotic cells for the massive degradation of cytoplasmic components in a lytic compartment within cells [13]. It is responsible for the turnover of cytoplasm [14], scavenging of unnecessary cellular components [15], formation of some tissues [16-18], and biotic [19-23] and abiotic stress responses [24-28]. Thus, autophagy helps to preserve cell homeostasis. Microscopic observations of cells can distinguish three types of autophagy: micro-, macro-, and mega-autophagy [12, $29,30]$. During microautophagy, a small fragment of sequestered cytoplasmic constituents is incorporated into the vacuole by invagination of the tonoplast membrane $[14,31]$. In macroautophagy, cellular material, or even entire organelles, intended for degradation are encapsulated in double-membrane vesicles called autophagosomes which are then transported to the vacuole. After fusion of the autophagosome and tonoplast membranes, the cytoplasmic cargo, contained a single membrane vesicle structure (autophagic body) is delivered into the vacuolar lumen [31]. Mega-autophagy, the third type of autophagy, begins with an intensive synthesis of hydrolytic enzymes, which results in enlarged vacuoles and increased tonoplast permeability. Finally, when the tonoplast is ruptured, the protoplast of the cell becomes acidified which leads to cell death [31].

The first evidence that autophagy plays a significant role in the controlled senescence of plant organs came from microscopic studies of senescing leaves of Triticum aestivum. Wittenbach et al. [32] observed that whole chloroplasts were present in the central vacuole which was filled with lytic hydrolases. In senescing petals of Ipomoea purpurea [33] and Dianthus caryophyllus [34], numerous vesicles containing fragments of degraded protoplast were observed. Similarly, in senescing fine roots of Populus trichocarpa, numerous autophagy-related structures have been observed [29]. As molecular tools developed, a plethora of mechanisms associated with autophagy were reported. In genetic screens of Saccharomyces cerevisiae for autophagy-defective yeast mutants, a number of ATG (AuTophaGy) genes required for autophagy were identified as being indispensable for the formation of autophagosomes during macroautophagy [13,35]. The ATG genes and their protein products are also highly conserved in plants [14] and their occurrence and activity have been described in detail in Arabidopsis [36-38], rice [39], and maize [40]. The central core of autophagy machinery, which is necessary for autophagosome assembly, consists of 18 ATG proteins. These proteins can be divided into four groups based on their function: (1) the ATG1 protein kinase complex, which is necessary for induction and coordination of autophagy; (2) the PI3 kinase complex that is involved in the recruitment of the ATG18-ATG2 complex to PI3P in the autophagic membrane through an interaction between ATG18 and PI3P (3) the ATG9 complex which plays a role in delivering lipids to the pre-autophagosomal structure, and (4) two ubiquitination-like systems involved in elongation and enclosure steps during autophagosome formation (ATG12, ATG8) [41]. Analyses of gene expression indicated a significant increase in the expression of ATG genes during the senescence of leaves and flower petals [12, 42-44]. A significant role of autophagy in the senescence process was also confirmed in studies utilizing Arabidopsis mutants that displayed early and fast leaf senescence phenotypes [9]. In that study, the authors also indicated an intriguing role for autophagy in the remobilization process. The atg mutants are characterized by hypersensitivity to nitrogen, reduced seed production, and inhibition in the formation of Rubisco-containing bodies (RCB) [9]. Similar to leaves and flower petals, most fine roots, in contrast to pioneer roots, are short-lived [45]. Despite all the information that has been forthcoming on senescence, autophagy, and remobilization in leaves and flower petals, a similar level of understanding of the process of senescence in fine roots is lacking.

The most recent classification scheme classifies fine roots as first, second, and third order roots with a diameter $<$ $2 \mathrm{~mm}$ [46]. They are characterized by a lack of secondary structure, the frequent presence of mycorrhizae, and a high surface to weight ratio [46]. These properties make them efficient in the absorption of water and minerals from the soil [47]. Fine roots, similar to leaves and flower petals, senesce and die after performing crucial functions that support plant growth and development. Root senescence and death have received a great deal of research interest over many years due to the importance of roots as a component of soil biomass and their effect on biological processes in forest ecosystems. The annual biomass production of fine roots is equal to or greater than the biomass of leaves, thus, the senescence and death of fine roots represent an important aspect of the cycling of chemical elements [48, 49].

In the present study, focus was placed on developing a more complete understanding of the process of fine root senescence relative to the same process in leaves. Despite the number of published root studies, few overall generalizations pertaining to the senescence process in roots have been established. This is perhaps principally because no conceptual framework exists for how root lifespan is constrained and controlled by cell or tissue physiology and genetics. While some theories to explain the control of fine root lifespan have been forwarded, very little data is available to evaluate these theories. Although this knowledge is crucial, obtaining high-quality data on this subject can be difficult and problematic. In the present study, we hypothesize that autophagy is an integral aspect of the senescence process in 
fine roots, as it is in seasonal leaf senescence, and that both processes are synchronized in their timing. We have conducted a significant amount of research to determine which morphological and cytological symptoms of root and leaf senescence are characteristic and either universal or unique to each organ. A molecular analysis of fine root senescence was also conducted, which provides the first evidence to support the premise that the senescence of fine roots can be seen as another example of developmentally programmed cell death (dPCD).

\section{Results}

\section{Structure of senescing fine roots and leaves of $P$. trichocarpa}

Fine roots and leaves were systematically monitored during the growing season to detect the first visible/measurable symptoms of senescence. Therefore, several morphological, anatomical, and cytological features were identified. Chlorophyll levels were also measured in leaves (Fig. 1). After an analysis we classified the material studied into six groups and these groups were used as experimental variants in other studies. The six classified groups were designated as: green leaves - control (LC); two stages of senescing leaves yellowing leaves (LS1) and yellow leaves (LS2); white fine roots - control (RC); and two stages of senescing roots light brown roots (RS1) and dark brown roots (RS2).

\section{Morphological symptoms of senescence and cell viability in senescing organs}

The pigmentation of both fine roots and leaves changed as the senescence process progressed (Fig. 2a-c; Fig. 3a-c). Fine roots changed in color from white to light brown to dark brown or black. A significant shrinkage in dark brown and black roots was also observed (Fig. 2b, c, h, i). Color changes in leaves were associated with decreases in chlorophyll content (Fig. 1; Fig. 3a-c). A viability assay was

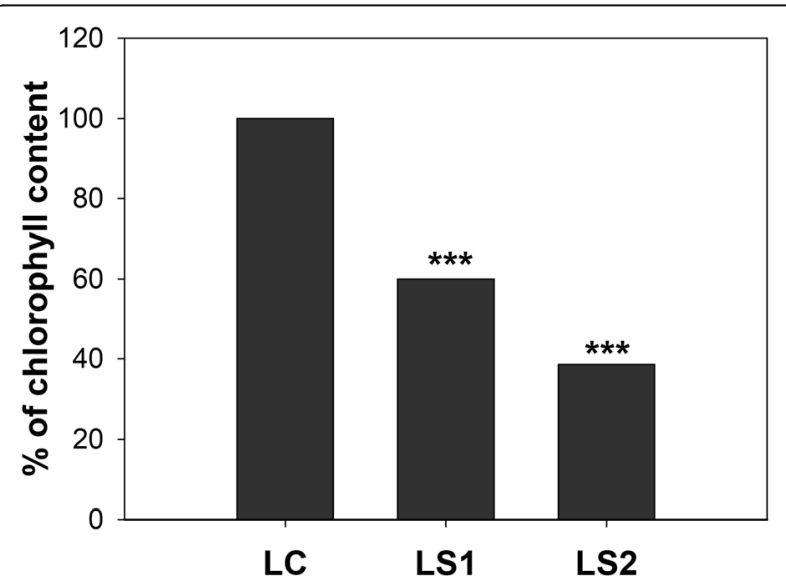

Fig. 1 Changes in chlorophyll level in leaves during the growing season conducted to determine if the changes in color were associated with a loss of cell viability in leaves and fine root tissues. A fluorescent signal was observed in the majority of cells of white fine roots (RC) and green leaves (LC) (Fig. 2d; Fig. 3d); indicating a high level of cell viability. The number of cells with a fluorescent signal in the light brown roots (RS1) and yellowing leaves (LS1), however, decreased relative to the signal levels in control samples (Fig. 2e; Fig. 3e). Lastly, the fluorescent signal in dark brown roots (RS2) and yellow leaves (LS2) was very low and was not present in many of the analyzed sections of tissues (Fig. 2f; Fig. 3f).

\section{Anatomical characteristics of senescence}

An anatomical analysis using light microscopy was conducted to identify anatomical changes that were characteristic of the senescence process in two organs (leaves and fine roots). Pronounced, progressive changes were observed in fine roots. At the beginning of the growing season, fine roots $(\mathrm{RC})$ were white and their morphology was round and regular (Fig. 2g). Internally, their cells had the appearance of features reflective of full turgor without any evidence of damage. The layer of cortical parenchyma cells was characterized by the presence of a large number of cells (Fig. 4a) without any evident signs of senescence. In the next two sampling periods (October and November), an increasing number of senescing roots were harvested. The most apparent characteristic in senescing fine roots (RS1 and RS2) were changes in their shape. Due to the occurrence of folded cell walls in cortical parenchyma cells, the morphological shape of the fine roots was not consistently round and regular, as had been observed in the $\mathrm{RC}$ root samples (Fig. 2h, i). This was confirmed by diameter measurements where a statistically significant decrease was apparent in RS1 and RS2 fine roots, relative to $\mathrm{RC}$ fine roots (Fig. 4b). Furthermore, many of fine roots collected at the RS2 stage were already dead and their overall structure was completely destroyed (Fig. 2i).

In contrast to fine roots, anatomical symptoms of senescence in leaves were not as readily evident (Fig. 3g-i). Significant changes in the shape of mesophyll cells were not observed, but the number of mesophyll cells was significantly lower relative to the control leaves (Fig. 3g-i). Measurements did not show statistically significant differences in the width of palisade mesophyll, however, a decrease in the leaf width occurred during the senescence process (Fig. 4c, d).

\section{Cytological analyses of senescing fine roots and leaves}

Based on the morphological and anatomical observations made of senescing leaf and fine root organs, cytological analyses focused on the cortical parenchyma cells of fine roots (Fig. 5) and the palisade and spongy mesophyll cells in leaves (Fig. 6). Cortical parenchyma cells in white, fine roots (RC) exhibited a regular shape with thin cell walls (Fig. 5a). 

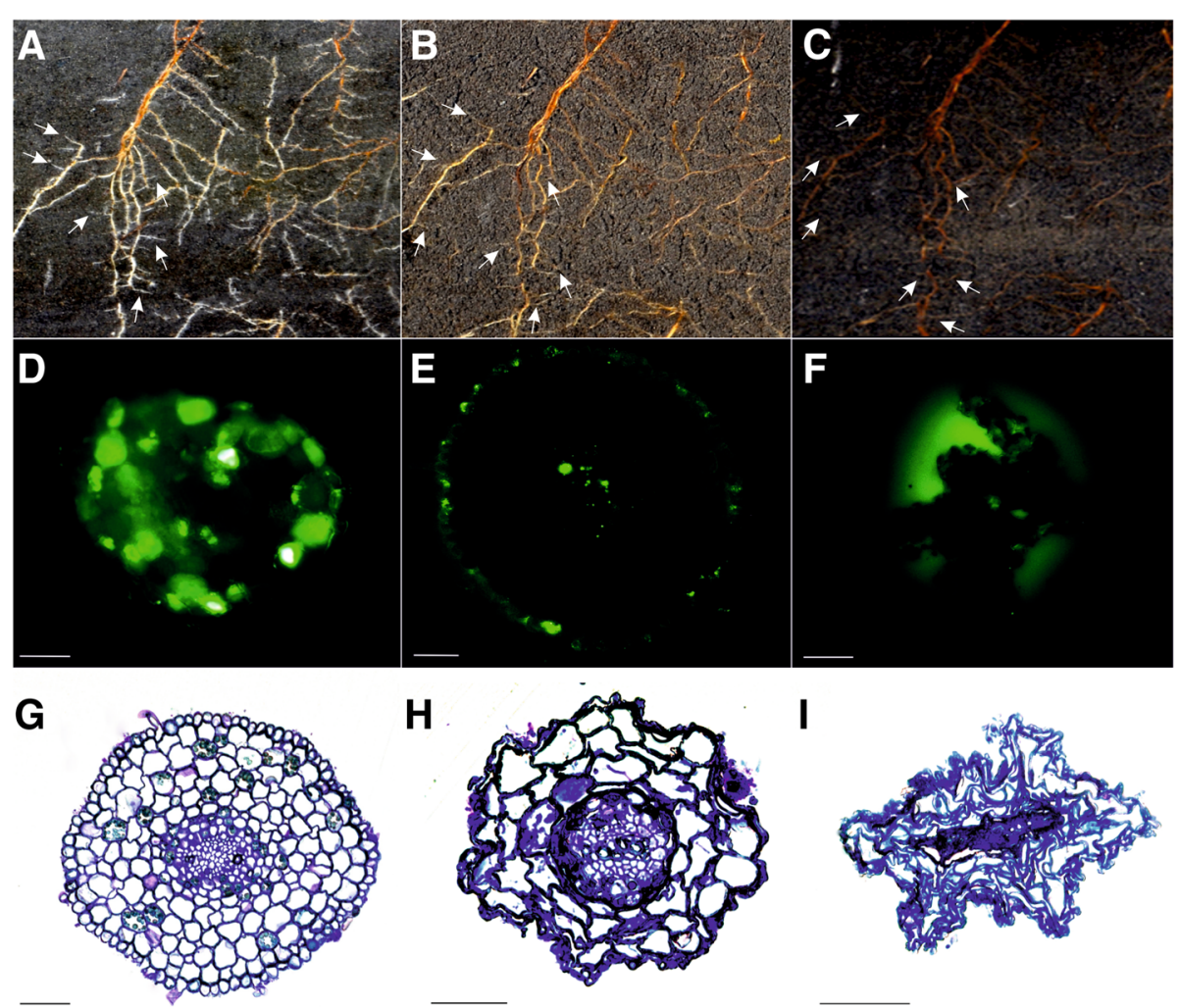

Fig. 2 Senescence-related changes in fine roots (a-c - changes in morphology; d-f - changes in cell viability; $\mathbf{g}$-i - changes in anatomy). Bars, 50 um

\section{A}
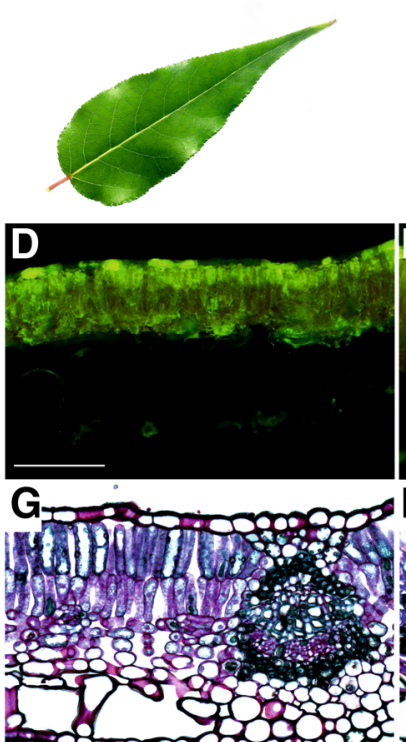

B
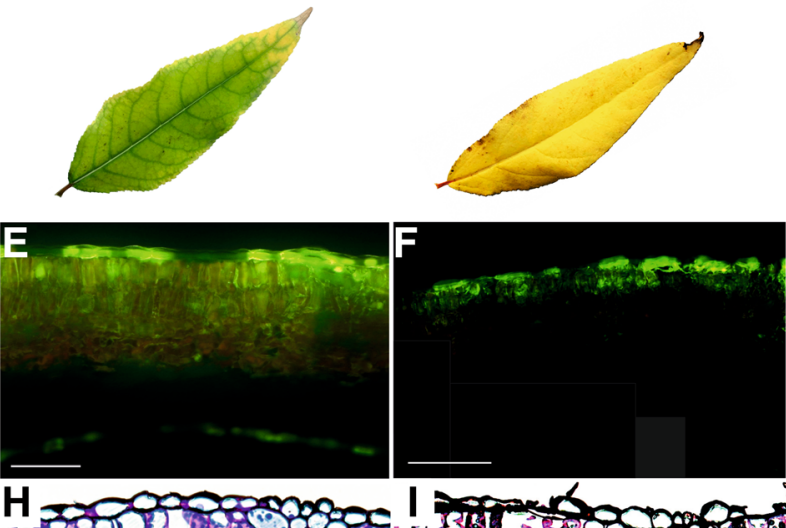

C
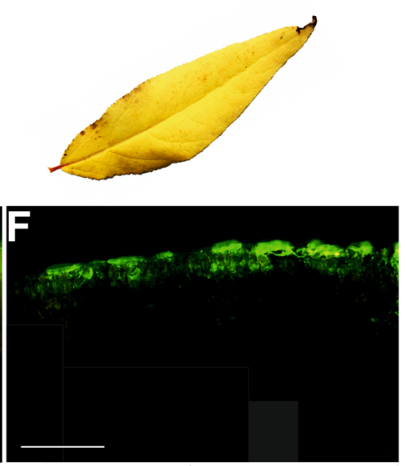

2)

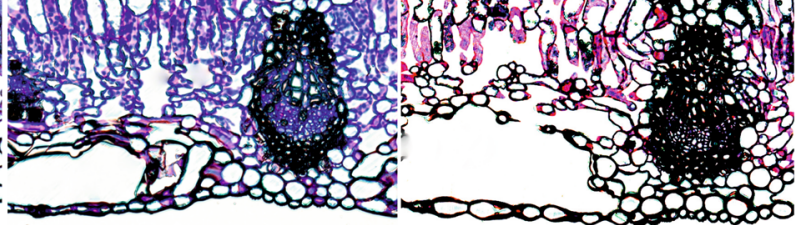

Fig. 3 Senescence-related changes in leaves (a-c - changes in morphology; $\mathbf{d}-\mathbf{f}$ - changes in cell viability; $\mathbf{g}$-i - changes in anatomy). Bars, 100 $\mu m$ 

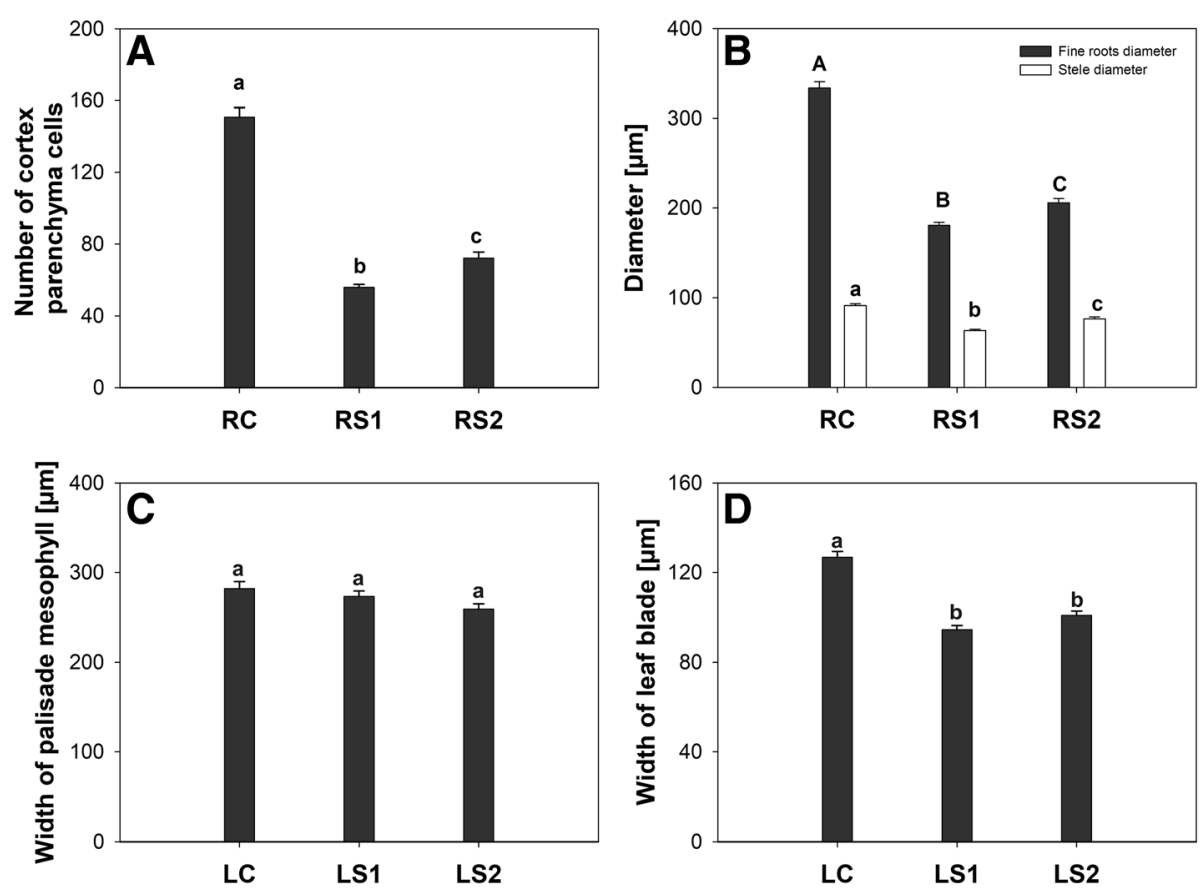

Fig. 4 Changes in the structure of fine roots and leaves in relationship to the senescence process. $\mathbf{a}$ - Number of cortical parenchyma cells per section of fine roots. $\mathbf{b}$ - Changes in the diameter of roots and the stele during senescence. $\mathbf{c}$ - Width of the palisade mesophyll in leaves of $P$. trichocarpa. $\mathbf{d}$ - Width of the leaf lamina in $P$. trichocarpa. Bars sharing the same letter are not significantly different $(P=0,05)$. Values represent the mean \pm SE (standard error)

A centrally located vacuole occupied most of the entire cell. The cytoplasm with its organelles was present as a thin band along the periphery of the cell wall (Fig. 5b). Tannins were observed in vacuoles of several cortical parenchyma cells, usually in close vicinity of the tonoplast (Fig. 5c). In contrast, evidence of senescence was readily observed in light brown (RS1) and dark brown (RS2) fine roots. The majority of cortical parenchyma cells in RS1 fine roots exhibited structures related to autophagy (Fig. 5d-f). Vesicles with cytoplasmic residues were observed in numerous cells. Those structures were similar to the vesicles present in cells undergoing microautophagy (Fig. 5d, e). Moreover, in RS2 cortical parenchyma cells, autophagic bodies inside vacuoles were also detected (Fig. 5g). Furthermore, the cell shape in the majority of RS2 cortical cells was more irregular than the oval shape of cells that were observed in RC and RS1 samples (Fig. 5h, i). Notably, cell walls were folded and the tonoplast was ruptured in cells that appeared to be in the last stage of senescence before dying. Furthermore, numerous microorganisms were observed in the external cortex of RS2 fine root samples (Fig. 5i).

Many changes in leaf ultrastructure related to the senescence process were also visible (Fig. 6). Control cells from LC were characterized by the presence of plenty organelles (mitochondria, endoplasmic reticulum and chloroplasts) with a normal appearance. Moreover, a significant number of starch granules were observed in both palisade
(Fig. 6a) and spongy mesophyll (Fig. 6b) cells. In contrast, the appearance of the majority of the cells from yellowing leaves (LS1) was distinctly different (Fig. 6d-f). Among the different organelles, the first and most rapid alterations in response to senescence were observed in chloroplasts where the internal structure was greatly modified (Fig. $6 \mathrm{~d})$. Ultrastructural analysis revealed the disintegration of thylakoids, with a concomitant massive formation of plastoglobules that were mostly located between the thylakoids within the senescing chloroplasts (Fig. 6d). Moreover, spherical bodies separating themselves from chloroplasts were observed in several cells, including Rubisco-containing bodies (RCB) (Fig. 6e). Furthermore, several different autophagy-related structures were observed in the cytoplasm, including autophagic bodies in the vacuole lumen (Fig. 6d) and autophagosomes (Fig. 6e). Evidence of the formation of these structures was also observed, seen as the joining of several tubules and vesicles (Fig. 6f). Many cells in yellow leaves (LS2) exhibited more advanced senescence-related changes (Fig. 6g-i). The structure of chloroplasts was more visibly altered, an increasing number and size of plastoglobules were observed (Fig. 6g), as well as more distended thylakoids. Ruptured tonoplasts were observed in several cells, which resulted in the degradation of all cellular structures due to the acidification of the cytoplasm that occurred once the tonoplast was ruptured (Fig. 6h, i). 


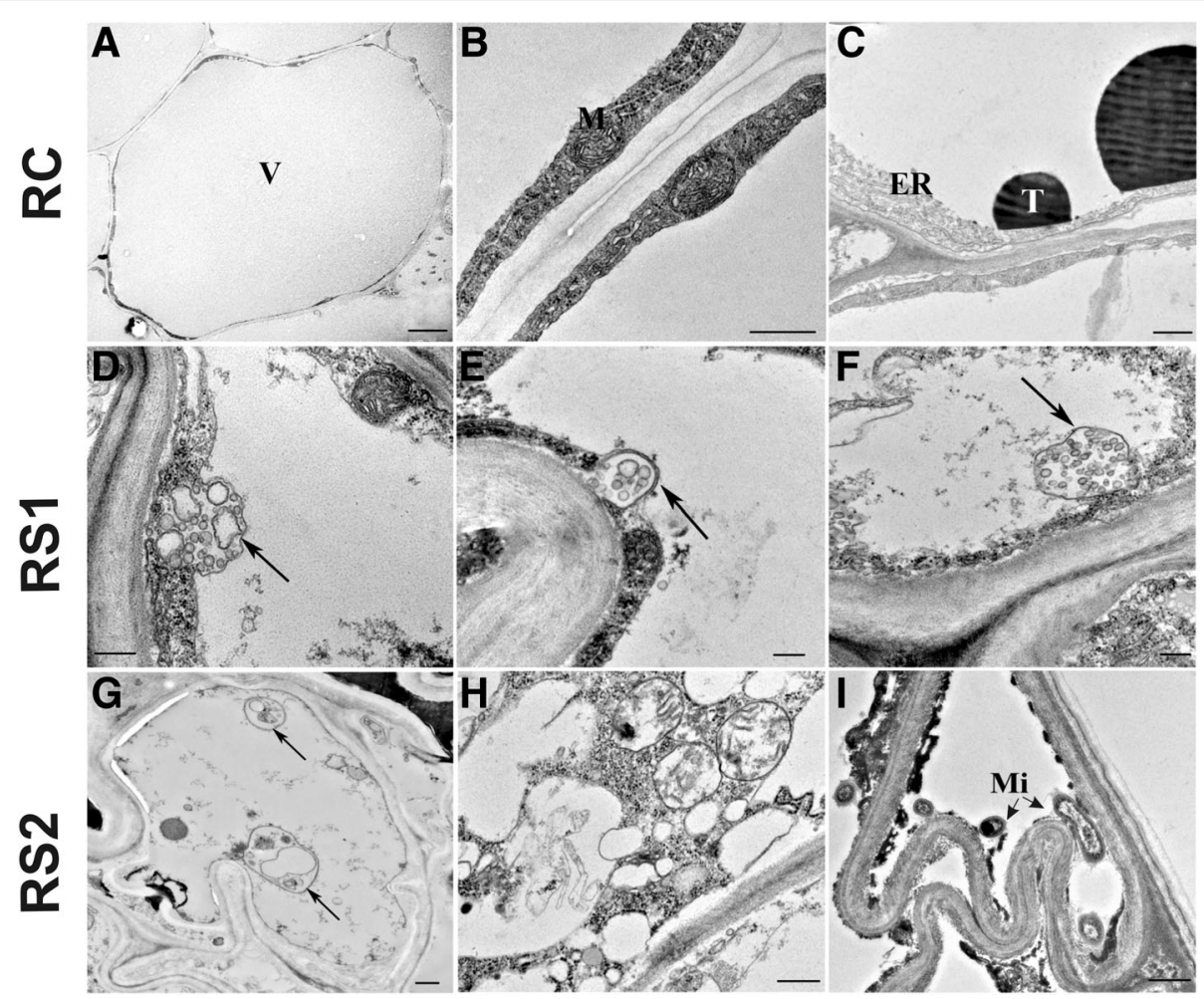

Fig. 5 Changes in ultrastructure of cortical parenchyma cells in fine roots during the course of senescence. a-c - white fine roots - control (RC); $\mathbf{d}-\mathbf{i}$ - two stages of senescing roots - light brown roots (RS1, $\mathbf{d}-\mathbf{f})$ and dark brown roots (RS2, $\mathbf{g}-\mathbf{i})$. Abbreviations: $V$ vacuole, ER endoplasmic reticulum, $M$ mitochondria, $T$ tannins, Mi microorganism. Arrows indicate autophagy-related structures. Bars, 0,5 $\mu \mathrm{m}$

\section{Expression of ATG genes during senescence}

The analysis of $A T G$ genes expression revealed significant differences in gene expression between control and senescing leaf and fine root tissues (LC vs LS and RC vs RS). The expression of ATG7, ATG8c, ATG8d, ATG8g, ATG8h, $A T G 11$, and $A T G 18$ were examined (Fig.7; Fig. 8). Statistically significant changes in the expression of majority ATG8 genes (ATG8c, ATG8d, ATG8g) were observed in fine roots (Fig. 7). Expression of all of these genes increased at the first stage (RS1) of senescence and then decreased in the second stage (RS2) of senescence (Fig. 7). In contrast, a slightly different pattern of expression was observed in leaf tissues. In contrast to roots, the expression of all of the examined ATG genes was upregulated in leaf tissues in both stages (LS1 and LS2) of senescence (Fig. 8). The largest increase in expression level was observed in the second stage (LS2) of senescence.

\section{Distribution and localization of ATG8 protein}

Based on the significantly increased expression of ATG genes in both roots and leaves, the amount and localization of ATG8 protein, which is necessary for appropriate autophagosome formation, was examined by immunoblot (Western blot) and immunolocalization analyses. ATG8 protein can be detected either as a protein conjugated to phosphatidylethanolamine (PE) on an autophagosomal membrane or as a free protein without PE. The level of ATG8 protein in both fine roots and leaves changed over the course of the growing season (Fig. 9a; Fig. 10a). Results indicated that the amount of ATG8 protein exhibited a similar pattern to changes in ATG8 gene expression.

The level of ATG8 was relatively low in viable, white roots (RC) (Fig. 9a). ATG8 was located mainly in xylem tissues or cells of the rhizodermis (Fig. 9b-d). A significant increase in the level of ATG8 was observed in the first stage (RS1) of senescence when fine roots appeared brownish (Fig. 9a). Both forms of ATG8 (free and conjugated to PE) were detected. ATG8 was localized in the majority of cortex parenchyma cells and in xylem tissues (Fig. 9e-g). ATG8 was detected in the cytoplasm, near the cell wall, or more concentrated in spherical bodies (Fig. 9e-g, arrows). Subsequently, when roots became dark brown (RS2), a slight decrease in the level of ATG8 was observed in fine root tissues. ATG8 conjugated to PE was the main form observed in RS2 fine root cells. The level of free protein was clearly lower in RS2 than in RS1 fine root cells (Fig. 9a). The localization of the conjugated and free protein did not appear to significantly change between the RS1 and RS2 stages of senescence (Fig. 9h-j). 


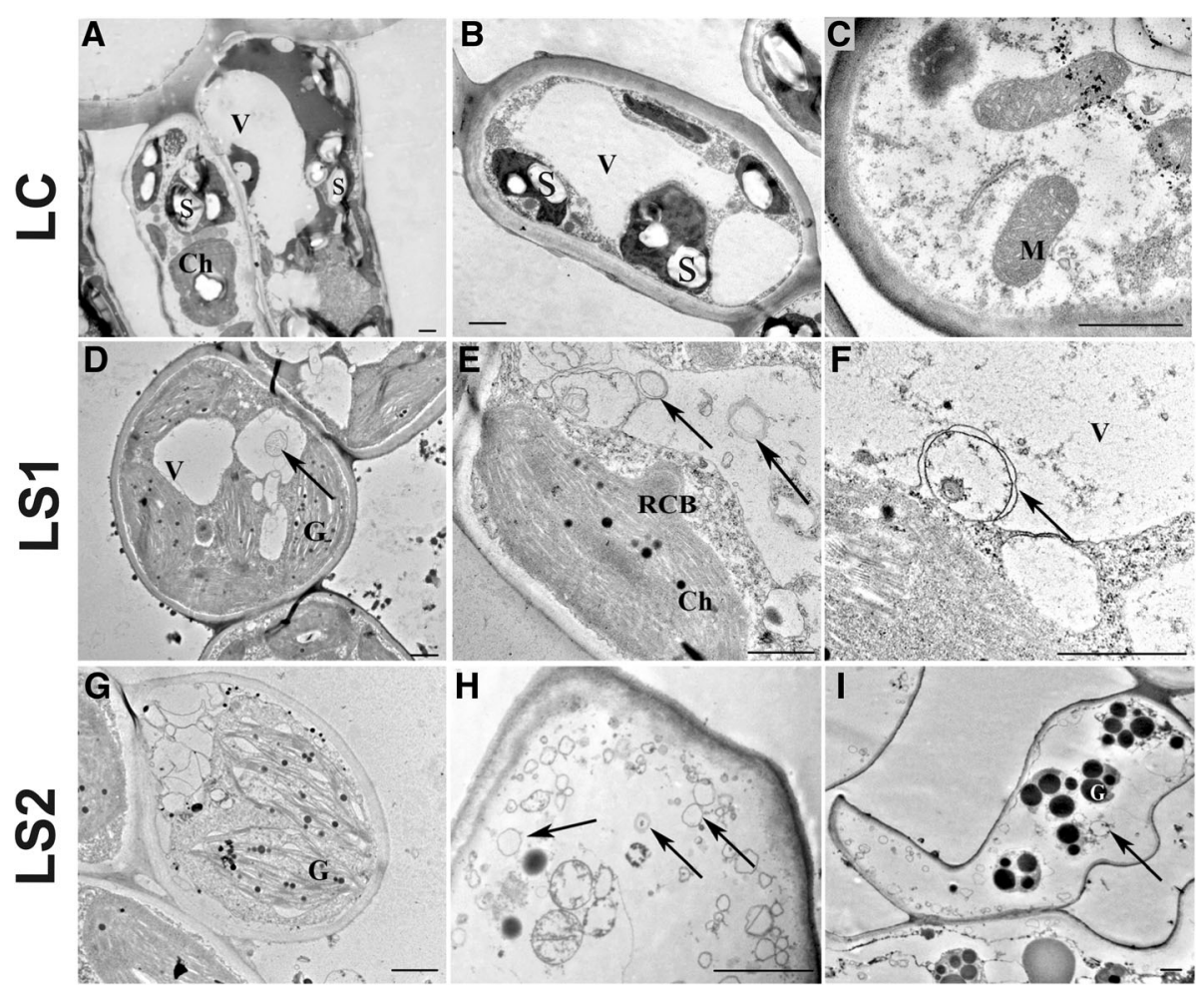

Fig. 6 Changes in ultrastructure of palisade and spongy mesophyll leaf cells during the course of senescence. a-c - green leaves - control (LC); $\mathbf{d}-\mathbf{i}$ - two stages of senescing leaves - yellowing leaves (LS1, $\mathbf{d}-\mathbf{f}$ ) and yellow leaves (LS2, $\mathbf{g}$-i) Abbreviations: $V$ vacuole, $S$ starch, $M$ mitochondria, $R C B$ Rubisco containing bodies, $\mathrm{G}$ gerontoplast, Ch chloroplast. Arrows indicate autophagy-related structures. Bars, $1 \mu \mathrm{m}$

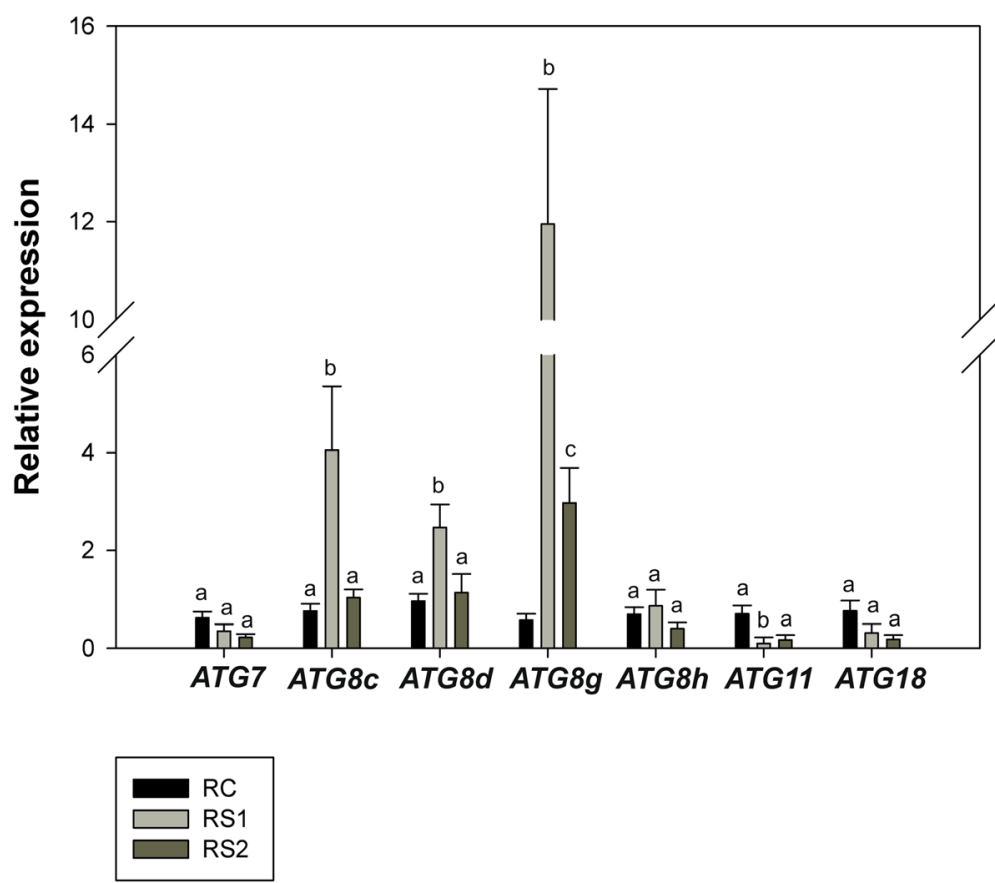

Fig. 7 Relative expression of ATG genes in fine roots (RC - root control, RS1 - first stage of root senescence, RS2 -second stage of root senescence) of Populus trichocarpa. Bars sharing the same letter are not significantly different $(P=0,05)$. Values represent the mean $\pm \mathrm{SE}$ (standard error) 

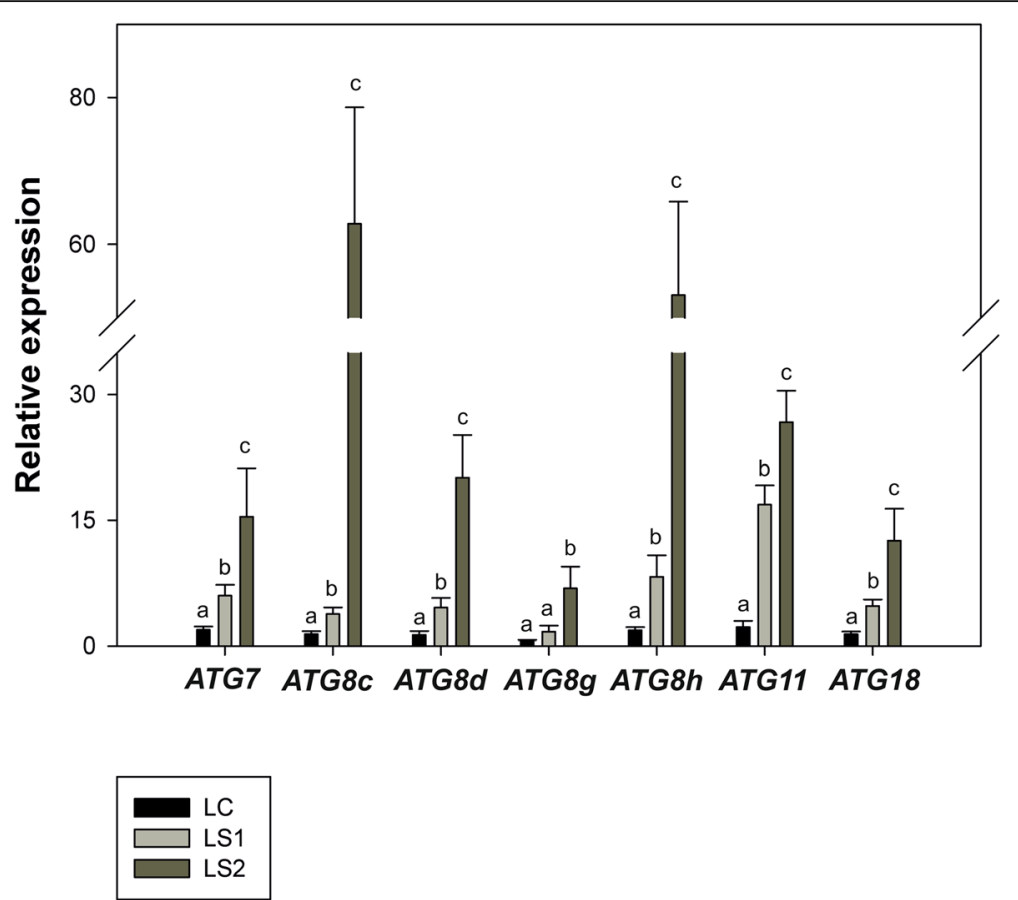

Fig. 8 Relative expression of ATG genes in leaves (LC - leaf control, LS1 -first stage of leaf senescence, LS2 - second stage of leaf senescence) of Populus trichocarpa. Bars sharing the same letter are not significantly different $(P=0,05)$. Values represent the mean \pm SE (standard error)

The level of the free form of ATG8, as well as the form in which ATG8 is conjugated to PE, was very low in green leaf (LC) tissues (Fig. 10a). A positive localization signal was mainly observed within the vascular bundle in xylem cells (Fig. 10b, c). In palisade and spongy mesophyll cells, ATG8 was localized in several cells but the signal level was relatively low (Fig. 10b-e). The level of ATG8 noticeably increased in yellowing leaves (LS1) and was mainly the form in which ATG8 is conjugated to PE (Fig. 10a). The signal was localized in epidermal cells, as well as the spongy and palisade mesophyll (Fig. 10f-i). ATG8 protein was mostly localized in spherical bodies (Fig. 10h, i, arrow) which were located in proximity to the cell wall. A significant level of localization also occurred in xylem vessels (Fig. 10f). A notable increase in the ATG8 level was observed in yellow leaves (LS2) (Fig. 10a). Microscopic analysis also revealed a strong localization of ATG protein in most cells (Fig. 10j-n). ATG8 protein was localized in cells of the epidermis, spongy and palisade mesophyll, and in xylem vessels. The distribution of ATG8 was similar in both the LS1 and LS2 stages of senescence, where it was concentrated in spherical bodies (Fig. 10j, m, n, arrow) but also dispersed in the cytoplasm (Fig. 10j-n).

\section{Discussion}

In this work, we emphasize the universality of senescence, which occurs in all ephemeral organs, and further indicate that regardless of the organ being examined, some aspects of senescence are common to all aging processes. Despite copious research conducted on programmed cell death in plants, a detailed understanding of the mechanisms underlying autophagy, which occurs during the senescence of all organs and tissues, is still insufficient. A key question is whether common mechanisms can be identified that are responsible for senescence in different plant organs? While the very precisely controlled death of specific cells during early development has been well described, the process of senescence in plants is well described only for leaves, fruits, and flower petals. Although senescence also occurs in below ground plant organs, this process is barely understood in root systems due to the difficulty in harvesting of roots. In spite of, or perhaps because of, these limitations, the present study compared the natural senescence process that occurs in two different plant organs: leaves and fine roots. We were interested to determine whether organs that serve completely different functions and possess a completely different structure undergo senescence in a similar manner. Morphological, anatomical, cytological, and molecular characteristics were used to analyze this question.

Utilizing the FDA viability tests, both fine roots and leaves were confirmed to undergo a gradual decrease in cell viability, along with morphological symptoms of senescence. Moreover, the decrease in viability observed in leaves and fine roots was synchronized in its timing, indicating that senescence in these two organs is induced by the seasonal change in environmental conditions. Our results are consistent with those obtained by Comas 


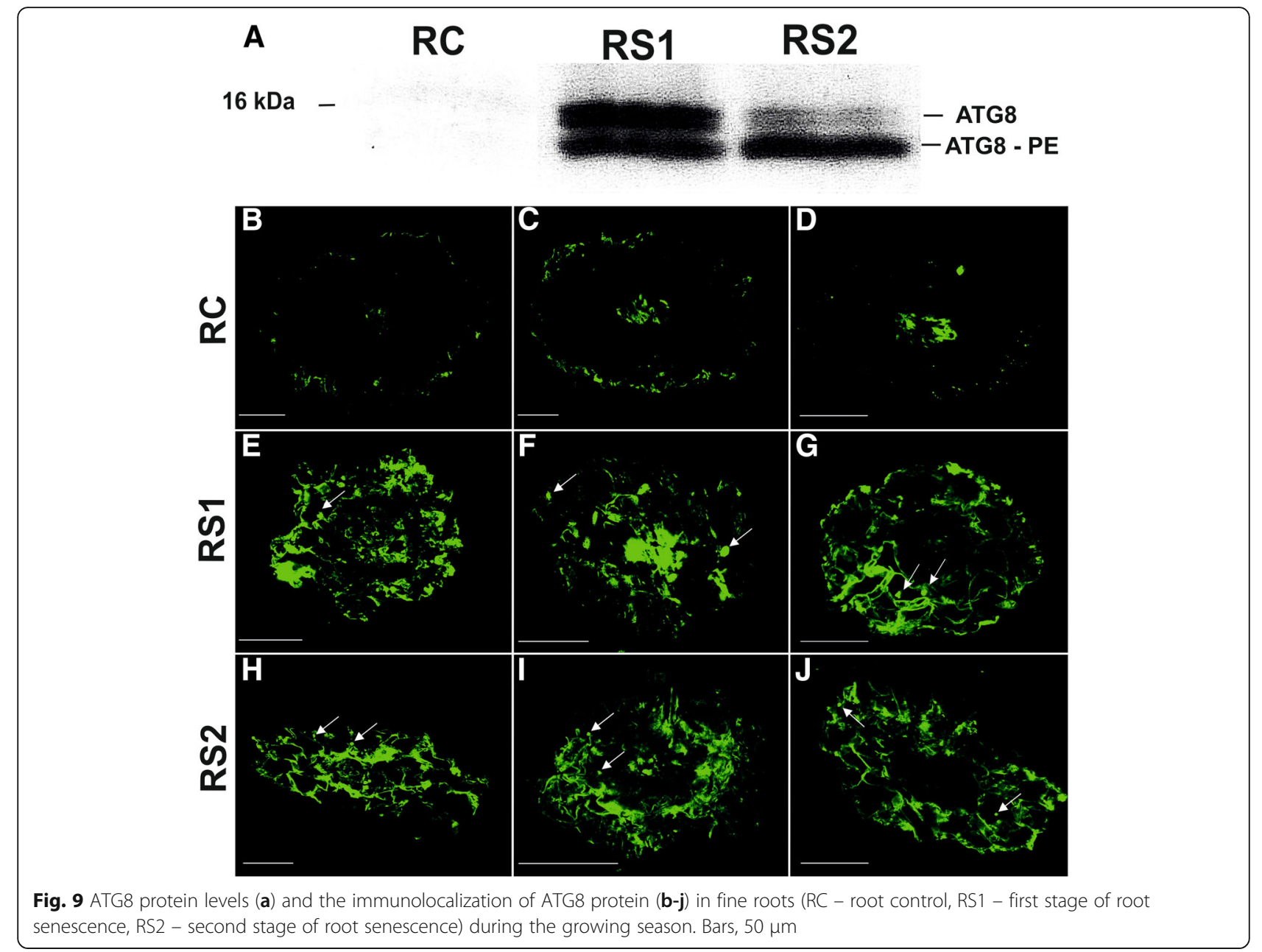

et al. [50] and Bagniewska-Zadworna et al. [29], who investigated the senescence of roots in Vitis labruscana and Populus trichocarpa, respectively. These studies also observed a progressive decrease in cell viability during the senescence process. The morphological features that were observed in our study were associated with a change in the pigmentation of the senescing organs and a shrinkage of the entire organ. Indeed, the first noticeable similarity in the senescence of fine roots and leaves was a change in color. The change in leaf color, which results from the degradation of chlorophyll, has been often described in numerous plant species, including Glycine max and Arabidopsis thaliana [51], Chenopodium quinoa [52], Gossypium hirsutum [53]. Chlorophyll degradation during leaf senescence exposes carotenoids [54], and is the cause of the change in leaf color that occurs in autumn in deciduous trees. The color change of flower petals, another ephemeral organ, has also been documented in several plant species from different plant families, including Ipomoea nil [55, 56], Nicotiana mutabilis [57], Antirrhinum majus [58], Argyranthemum frutescens [58], and Petunia hybrida [59]. The senescing petals of Hibiscus syriacus become blueish when the ratio of flavonoids and anthocyanins changes and alters the $\mathrm{pH}$ of the cytoplasm [60].

Another morphological characteristic that occurs universally during the senescence of every ephemeral organ is shrinking and/or wilting [2]. In the present study, shrinkage was evident during the senescence of most fine roots of Populus trichocarpa in the second stage (RS2) of senescence. This observation is similar to the reports in earlier root studies $[29,50]$. In contrast, a decrease was observed in the width of the leaf blades of Populus trichocarpa during leaf senescence. This may have been related to a loss in cell turgor, which makes the leaves appear withered.

A common sequence of events during the senescence of fine roots and leaves was also observed at an ultrastructural level. In both organs, the shape of cells became irregular and altered during the senescence process, which was in sharp contrast to the regular outline of cell shape observed at the beginning of the growth season. It is plausible that the change in cell shape may have been induced by an impairment of the cytoskeleton [61]. Early degradation of the lattice formed by cortical microtubules 

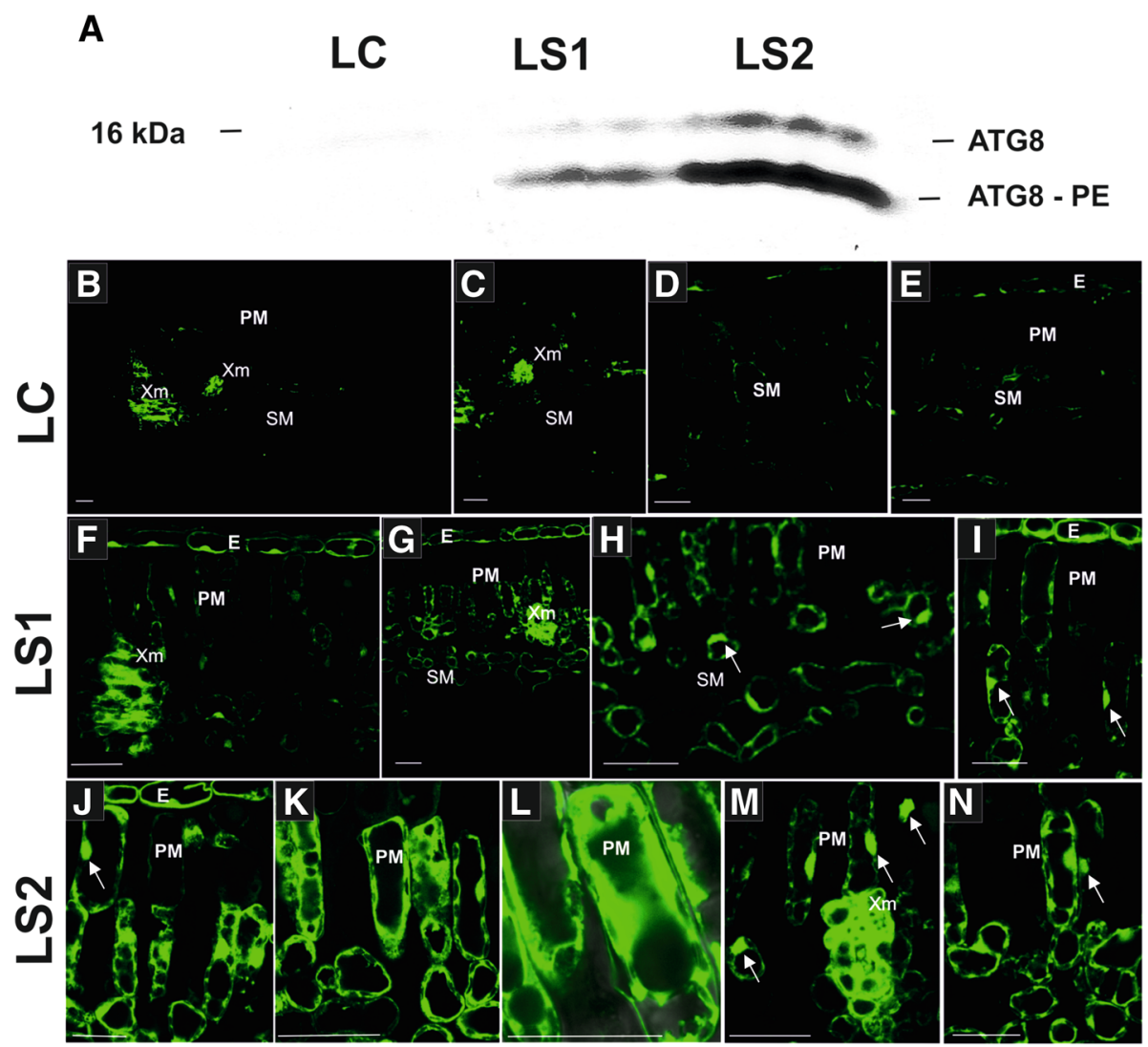

Fig. 10 ATG8 protein levels (a) and the immunolocalization of ATG8 protein (b-n) in leaves (LC - leaf control, LS1 - first stage of leaf senescence, LS2 - second stage of leaf senescence) during the growing season. (Abbreviations: Xm xylem vessels, PM palisade mesophyll, SM spongy palisade, E epidermis). Bars, $25 \mu \mathrm{m}$

was reported to occur during both natural and dark-induced senescence of Arabidopsis leaves [61]. The expression of genes related to the cytoskeleton, such as $\alpha-$, $\beta$-, and $\gamma$-tubulins, were also reported to be repressed during leaf senescence [42].

Another common feature of the senescence process appears to be the occurrence of autophagy, which has been observed to occur at the beginning of senescence, evidenced by the accumulation of a large number of vesicles in senescing cells. These vesicles most likely formed through micro and/or macroautophagy, as evidenced by their localization and appearance, which indicated vesicle formation. The formation of multiple vesicles by the fusion of several tubules was evidence of macroautophagy according to van Doorn and Papini [62]. Spherical bodies separated from chloroplast, and remaining Rubisco-containing bodies ( $\mathrm{RCB}$ ) were also observed in leaf cells in the present study. RCB bodies are double-membrane vesicles which contain chloroplast proteins such as Rubisco and Gln synthetase [63, 64]. The presence of numerous double membraned vesicles was also observed in senescing petals of Ipomoea purpurea [33] and Dianthus caryophyllus [34]. These observations indicate that autophagy plays an important functional role during the senescence of all ephemeral organs, where it is equally responsible for degradation of cellular components and the selective recycling and remobilization of chemical constituents.

Autophagy is a universal mechanism in cells that is responsible for the degradation of aberrant proteins and damaged organelles so that cellular homeostasis is maintained $[65,66]$. Autophagy is typically accompanied by the process of programmed cell death (PCD). This relationship has been confirmed during various developmental events in plants, such as xylogenesis [67], anther development [16], tapetum degradation [16], and the hypersensitive response (HR) [21]. Similar mechanisms may regulate cell death during the senescence of leaves and flower petals $[43,55,64,68,69]$. A significant knowledge gap still exists, however, regarding the presence of autophagy in the senescence of fine roots and details of its functional role.

Similar to the senescence process in leaves and petals, autophagy in fine roots is also involved in the disintegration of membranes, and delivering unwanted cytoplasmic material, such as targeted proteins, carbohydrates, and lipids, to vacuoles for breakdown; thus replenishing the supply of nutrients 
needed for normal cell function. Therefore, autophagy often plays a dual antagonistic role as executioner and as a mediating, dilatory factor in senescence. Ultrastructural studies performed on senescing leaves and fine roots of $P$. trichocarpa in the present study provided many general observations. Many autophagy-related structures were observed in the cytoplasm and vacuole lumens of both leaf and fine root cells. To provide evidence supporting the origin of these vesicles and their association with autophagy in both organs, $A T G$ gene expression and ATG protein levels were analyzed. The expression of the selected ATG genes increased in both leaf and fine root tissues during senescence. The highest increase in expression among the analyzed genes was observed for ATG8 genes. ATG8, is a ubiquitin-like peptide tag which is necessary for formation of autophagosomes and is responsible for regulating their size [13, 70, 71]. ATG8 is conjugated to phosphatidylethanolamine (PE) on an autophagosomal membrane by a bond between the carboxyl-terminal glycine (Gly) of ATG8 and PE [12]. In various studies, ATG8 and its homologs (LC3 in mammals) was used as a reliable marker for the induction and progression of autophagy. Several ATG8 genes have been identified in the plants [72]. The expression of ATG8 genes observed in the present study in senescing organs (leaves and fine roots) of $P$. trichocarpa was slightly different in the two organs. In leaves, $A T G 8 c$ and $A T G 8 h$ exhibited the highest level of expression, while $A T G 8 g$ was the most upregulated in fine roots. Tissue-specific expression of ATG8 genes has also been observed in Arabidopsis [72]. During developmental and dark-induced senescence, ATG8 expression has been reported to increase in leaves of Arabidopsis thaliana [42] and Hordeum vulgare [44], as well as in senescing petals of Petunia hybrida and Impomea nil [12, 65]. The involvement of autophagy in senescing fine roots was convincingly confirmed in our study by protein analysis, which indicated that the level of ATG8 protein significantly increased in senescing roots. ATG8 protein was localized in the cytoplasm and highly concentrated in specific, membrane bound structures. A similar observation was reported by Thompson et al. [72], who detected ATG8 fused with GFP in hypocotyl cells of young seedlings during $\mathrm{N}$ starvation.

Only a few studies can be identified where meaningful evidence of the dual role of autophagy during the senescence of plant organs has been provided. Although the dual role of autophagy as both a pro-survival and pro-death process was recently discussed [41], most studies have only focused on its role in the process of degradation. In the 1980s, electron microscopy provided visual evidence of chloroplast degradation and the presence of degraded chloroplast components in vacuoles [32]. Later, Ishida et al. [63] reported the accumulation of small bodies, which were designated as Rubisco containing bodies (RCB) based on their composition, in senescing leaves of Triticum aestivum. Plants constitutively expressing stroma-targeted GFP demonstrated that the accumulation of the GFP signal was localized in the vacuolar lumen of cells treated with concanamycin A, a drug that inhibits the degradation of autophagic bodies in the vacuole. Interestingly, RCB bodies were not observed in the cells of atg 5 mutants, suggesting that the autophagy-dependent process is responsible for the degradation of chloroplasts. A similar result was obtained with Arabidopsis mutants, atg $4 a$, atg $4 b-1$, which exhibit autophagy disorders and where RCB bodies were also not detected [73]. Degradation of chloroplasts by autophagy was unequivocally confirmed in studies where co-expressed stroma-targeted RFP and ATG8 fused with GFP colocalized in the vacuole of leaves $[63,74]$. Autophagy plays the role of an executioner in the last stage of senescence process when increased permeability and eventual rupturing of the tonoplast membrane; resulting in the release of hydrolytic enzymes which cannibalize the protoplast and cause cell death [66]. Rupture of the tonoplast membrane represents the point-of-no-return and the described sequence of events has been observed in senescing leaves [75], flower petals [33], and fine roots [29].

Much less attention has been paid to the role of selective autophagy in the remobilization process [9-11]. Additionally, knowledge concerning the mechanisms and function of autophagy in nutrient availability and recycling in plants is less advanced for roots than it is for leaves. The first evidence for the role of autophagy in remobilization was provided in studies of Arabidopsis leaf senescence [9]. Genetic and molecular analyses utilizing mutants with impaired ATG genes help to document the biological function of autophagy in remobilization. Using wild-type (WT) and atg mutants of $A$. thaliana treated with $15 \mathrm{NO}_{3}{ }^{-}$, the level of $15 \mathrm{~N}$ was evaluated. Results indicated that remobilization was significantly lower in the atg mutants than in WT plants [9]. Interesting results regarding the relationship between autophagy and remobilization during senescence came from a study of maize atg12 mutants [11]. This study demonstrated that $15 \mathrm{~N}$ remobilization to seeds was altered in atg12 autophagy-defective mutants. Surprisingly, the relocation of nitrogen to newly-formed leaves was greater in the atg12 autophagy-defective mutants as compared to WT. Remobilization of nutrients is also observed during the senescence of flower petals. Quantitative analysis of nitrogen in Petunia hybrida flowers demonstrated that the level of $\mathrm{N}$ changed before and after pollination-induced senescence in the examined parts of a flower. Nitrogen content decreased in petals and increased in the ovaries of pollinated flowers [12].

The role of autophagy in remobilization is also essential in fine roots. Fine roots are characterized by a short lifespan which typically does not exceed two years [76, 77]. In Populus, the life-span of fine roots is usually 
$<95$ days [78]. Considering that the biomass of fine roots is equal to or greater than the biomass of leaves, remobilization is an important subject when discussing the cycling and recycling of chemical elements [48, 49]. Our current study indicated that the autophagy machinery is present and active in senescing fine roots, and suggests that substantial amounts of the elements stored in fine roots are remobilized to other parts of the plant. How large a portion is released to the soil may be also regulated by autophagy. Identifying the reason and underlying mechanism for the induction of autophagy and its biological function during the time period prior to the final death of fine roots will require additional studies.

\section{Conclusion}

The senescence of plant organs, despite its destructive character, is a genetically controlled process that follows a well-defined sequence of events and is regulated by multiple pathways [2]. Cell viability is also essential for the initiation and progression of cell senescence. As long as a cell is viable, autophagic processes can be utilized to continue the process of degradation and remobilization in a controlled manner without crossing the point-of-no return and the final result, cell death. Our study comparing the senescence process in fine roots and leaves, helps to establish a cohesive model of the process of senescence in ephemeral organs. The combination of current and long-established information, clearly indicates that autophagy is a multifaceted system that plays a role in both the degradation of unwanted, unneeded cellular material, and the remobilization of valuable nutrients. How autophagy regulates cell survival and death however, is still not well understood and should be a priority for future research.

\section{Methods}

\section{Plant material and growth conditions}

All experiments were performed on fine roots and leaves of Populus trichocarpa (Torr. \& Gray) growing at an experimental field site at the Institute of Dendrology, Polish Academy of Sciences in Kórnik (52 $14^{\prime} 40^{\prime \prime} \mathrm{N}$ and $17^{\circ} 06^{\prime} 27^{\prime \prime}$ ).

Seeds were obtained from the FLORPAK Młynki Seeds Store, Poland. Seedlings were initially grown in a plant growth chamber (Conviron GR96) at $18{ }^{\circ} \mathrm{C}$ day $/ 14{ }^{\circ} \mathrm{C}$ night and a $16 \mathrm{~h}$ day $/ 8 \mathrm{~h}$ night photoperiod. After 3 months, plants were transferred into rhizotrons. The rhizotrons $(50 \times 30 \mathrm{~cm})$ were constructed of two transparent polycarbonate plates held $3 \mathrm{~cm}$ apart by thick-walled plastic tubing to provide sufficient growing space. The rhizotrons were placed in an underground chamber. They combine the controlled conditions of laboratory experiments with the advantages of a natural field setting. Waterlogging was avoided by providing a drainage hole in the bottom of each rhizotron. This permitted soil aeration and drainage of excess water. An automated system was used for the watering of individual plants. Plants were grown in rhizotrons consisting of clear-walled chambers filled with natural soil that allow shoots to grow above the soil surface. Rhizotrons were installed in a semi-open, foil greenhouse, to prevent flooding and heat stress. The rhizotrons provide the ability to collect root growth measurements over time without disturbing aboveground plant growth and without the need for destructive sampling of roots until deemed necessary based on the experimental design.

Senescent leaves were identified based on chlorophyll measurements (Fig. 1) and senescent roots were identified based on symptoms as defined by Comas et al. [50]. Additional data obtained on anatomy, cytology and a viability test were also taken into account when interpreting the collected data.

Samples were collected three times during a growth season. The first collection was considered as a control and was collected in early summer (July 7-15) when leaves and the root system were fully developed and functional. Control leaf samples were designated as LC and control fine root samples were designated as RC. The second group of leaf and root samples were harvested in early autumn (October 1-7) when chlorophyll levels in leaves had decreased by approximately $40 \%$ (Fig. 1) and when fine roots had changed in color from white to brown. The first stage of leaf senescence was designated as LS1 and the first stage of fine root senescence was designated as RS1. The third group of samples were harvested in the middle of autumn (November 2-9) when chlorophyll levels in leaves decreased by approximately 65\% (Fig. 1) and fine roots were dark brown or black color. The second stage of leaf senescence was designated as LS2 and the second stage of fine root senescence was designated as RS2.

\section{Morphological studies}

Photographic documentation of leaves was collected along with chlorophyll measurements to better illustrate the relationship between the two parameters during the senescence process. Chlorophyll levels were measured several times during the growth season using a CCM-200 plus Chlorophyll Content Meter (Opti-Sciences). Changes in the morphology of fine roots were examined several times during the growth season. This was done by removing the rhizotrons from the chamber and taking photos of the root systems, and immediately returning them back into the chamber. The same 30 plants were analyzed each time.

\section{Viability test using a fluorescein diacetate (FDA) staining assay}

The viability of cells in fine roots and leaves was assessed with fluorescein diacetate (FDA)(Sigma). After harvesting, fine roots and leaves were cut into $35 \mu \mathrm{m}$ thick 
cross-sections using a Leica VT1200S vibratome (Leica Biosystems, Nussloch, Germany). The sections were transferred to $100 \mu \mathrm{l}$ of a diluted stock solution of FDA (stock solution $5 \mathrm{mg}$ FDA in $1 \mathrm{ml}$ of acetone, stock solution diluted 1:250 in Phosphate-buffered saline (PBS) (Sigma). After a $15 \mathrm{~min}$ incubation period at room temperature (RT), sections were rinsed three times in PBS buffer. Fluorescence was only observed in live cells due the conversion of non-fluorescent fluorescein diacetate into fluorescein. Fluorescence was induced by exposure to a wavelength of $470 \mathrm{~nm}$ (blue excitation and green fluorescence) under an Axioscope A1 microscope (Zeiss, Jena, Germany). Fluorescence images were digitally captured.

\section{Anatomical studies}

The harvested samples of fine roots and leaves were immediately fixed in a mix $2 \%(\mathrm{v} / \mathrm{v})$ glutaraldehyde $(\mathrm{pH} 6.8$; Polysciences, Warrington, USA) and 2\% (v/v) formaldehyde ( $\mathrm{pH}$ 6.8; Polysciences, Warrington, USA). After an overnight incubation in fixative solution, the samples were rinsed three times with a cacodylate buffer (0.05 M; pH 6.8; Polysciences) and then dehydrated in a graded ethanol series $(10-100 \%, v / v)$. Subsequently, the samples were incubated in a series of ethanol:Technovit 7100 resin mixture (Heraeus Kulzer, Wehrheim, Germany) with ratios of 3:1, 1:1, 1:3, and finally in pure Technovit 7100 resin. Cross-sections were cut with a Leica RM2265 Fully Automated Rotary microtome (Leica-Reichert, Bensheim, Germany) at a thickness of $10 \mu \mathrm{m}$. The cross-sections were stained with $1 \%(\mathrm{~m} / \mathrm{v})$ aniline blue and examined under a light microscope (Axioscope A1, Carl Zeiss, Jena, Germany).

\section{Cytological studies}

For cytological studies, the fragments of fine roots and leaves were fixed in $2 \%(\mathrm{v} / \mathrm{v})$ glutaraldehyde $(\mathrm{pH} 6.8$; Polysciences, Warrington, USA) and $2 \%$ formaldehyde $(\mathrm{v} / \mathrm{v})\left(\mathrm{pH} 6.8\right.$; Polysciences, Warrington, USA) at $4{ }^{\circ} \mathrm{C}$ overnight. Subsequently, the samples were rinsed three times with a cacodylate buffer (0.05 M; pH 6.8, Polysciences) and postfixed in $1 \%(\mathrm{v} / \mathrm{v})$ osmium tetroxide (Polysciences) at RT for $2 \mathrm{~h}$. The double fixed material was counterstained for $1 \mathrm{~h}$ with $2 \%$ uranyl acetate (Polysciences) and embedded in low viscosity resin using the method described by Zenkteler and Bagniewska Zadworna [79]. Ultrathin sections (70 nm) were cut on a Leica EM UC7 (Leica-Reichert, Bensheim, Germany) ultramicrotome using a diamond knife and cut sections were collected on formvarcoated copper grids. The sections were stained with uranyl acetate and lead citrate, and examined with a Hitachi HT7700 transmission electron microscope
(Hitachi, Tokyo, Japan) operating at an accelerating voltage of $80 \mathrm{kV}$.

\section{Protein extraction, gel electrophoresis, and western blot analysis}

Total protein was extracted from the collected samples according to the method described by Szuba et al. [80], which is based on phenol extraction. After extraction, proteins were solubilized in a buffer containing $7 \mathrm{M}$ urea, $2 \mathrm{M}$ thiourea, $40 \mathrm{mM}$ dithiothreitol (DTT), 0.5\% carrier ampholytes, and 4\% CHAPS. Protein concentration was measured with a 2-D Quant Kit (GE Healthcare, Piscataway, USA). Proteins were separated by SDS-PAGE on $12 \%$ polyacrylamide gels, with an equal amount of protein $(20 \mu \mathrm{g})$ in each lane. The western blot analysis was performed according to the method described by Kalemba and Litkowiec [81]. A primary antibody - anti-ATG8 (Agrisera) was diluted 1:1000. The presence of reactive protein was visualized on a membrane using an alkaline phosphate substrate (5-bromo-4-chloro-3-indolyl phosphate/nitro blue tetrazolium) (Sigma Aldrich, St. Louis, USA).

\section{RT-qPCR analysis of gene expression}

RNA isolation was performed with a Ribospin Plant kit (GeneAll Biotechnology Co., Ltd., Korea) according to the manufacturer's recommendations. RNA was suspended in nuclease free water and stored at $-80{ }^{\circ} \mathrm{C}$. cDNA synthesis was performed using a High Capacity cDNA Reverse Transcription kit (Applied Biosystems, Thermo Fisher Scientific Inc., USA) following the protocol supplied by the manufacturer. Reverse transcription - quantitative PCR (RT-qPCR) was carried out using a SYBR Green Master Mix kit (Applied Biosystems, Thermo Fisher Scientific Inc., USA). All analyses of gene expression by RT-qPCR utilized three technical replicates from three biological replicates of each experimental variant. Analyses were conducted in 96-well plates in a CFX96 Touch Real-Time PCR Detection System (Bio-Rad Laboratories, Inc., USA) utilizing the following amplification program: denaturation by a hot start at $95{ }^{\circ} \mathrm{C}$ for $10 \mathrm{~min}$, followed by 40 cycles of a two-step program (denaturation at $95{ }^{\circ} \mathrm{C}$ for $15 \mathrm{~s}$ and annealing/ extension at $60{ }^{\circ} \mathrm{C}$ for $1 \mathrm{~min}$ ). Primers used in this study were designed using Primer3 software (The Whitehead Institute for Biomedical Research, Cambridge, MD, USA). The sequences of the primer pairs are listed in Table 1. Several reference genes (such as: GADPH, Actin, $18 S$ rRNA, $\beta$-Tubulin, PKFE, EF1a, NADH, and Ubiquitin) were utilized. $\beta$-Tubulin, GAPDH, and Ubiquitin were selected as housekeeping genes and for normalization of expression values because they exhibited the lowest sample to sample variation and high stable expression in all samples types and time points. 
Table 1 List of primer sequences used for RT-qPCR analyses

\begin{tabular}{|c|c|}
\hline Gene & Primer Sequences \\
\hline$\overline{\text { ATG7 }}$ & $\begin{array}{l}\text { F - 5'-GGAATCGAATTCCTGCTTCA-3' } \\
\text { R - 5'-TGTCTCATCATCCCAGTCCA-3' }\end{array}$ \\
\hline ATG8C & $\begin{array}{l}\text { F - 5'-TGCCTGTGTTACGGATCTTG-3' } \\
\text { R - 5'-ACCCCAAATGTGTTCTCACC-3' }\end{array}$ \\
\hline ATG8d & $\begin{array}{l}F-5^{\prime} \text {-GCCAACAGTGAGATCAGCAG-3' } \\
R-5^{\prime}-\text { GGGACTTTGTAGGTGTGCT-3' }\end{array}$ \\
\hline ATG8g & $\begin{array}{l}\text { F - 5'-CGTTGCCTCAAACAGCAAGT -3' } \\
\text { R - 5'-AGAAAGGATGATACAGCTTAGCCA-3' }\end{array}$ \\
\hline ATGBh & $\begin{array}{l}\text { F - 5'-TAGAGAGGTGGTTGGGTGCT-3' } \\
\text { R - 5'-CCTGCTTCTGACCCTTCTTG-3' }\end{array}$ \\
\hline ATG11 & $\begin{array}{l}\text { F- 5'- AGAGCTGCTTGACAAGTACCCA-3' } \\
\text { R- 5'-CTTTCCTTGTTTGCCTGCTTCT-3' }\end{array}$ \\
\hline ATG18 & $\begin{array}{l}\text { F - 5'-GACAATGACGAGCCAGGATT-3' } \\
\text { R - 5'- AGAGTTCGAGTGGCTGGAGA-3' }\end{array}$ \\
\hline B-TUBULIN & $\begin{array}{l}F-5^{\prime}-T T C T C C T G A A C A T G G C A G T G-3^{\prime} \\
R-5^{\prime}-C C A C A C A A C G T G A A T C C A G-3^{\prime}\end{array}$ \\
\hline GAPDH & $\begin{array}{l}\text { F - 5'-CAATGAATGGGGCTACAGGT-3' } \\
R-5^{\prime} \text {-CATGAATCAGCTGCACATCC-3' }\end{array}$ \\
\hline UBIQUITIN & $\begin{array}{l}\text { F - 5'-AGGAACGCGTTGAGGAGAAG -3' } \\
\text { R - 5'-TATAABCAAAAACCGCCCCTG }-3^{\prime}\end{array}$ \\
\hline
\end{tabular}

$F$ forward primer, $R$ reverse primer

Data analyses were performed according to the method described by Bagniewska-Zadworna and Stelmasik [82]. The average cycle threshold $(\mathrm{Ct})$ values of the reference genes were subtracted from the corresponding $\mathrm{Ct}$ value of each gene to obtain a ${ }^{\Delta} \mathrm{Ct}$ value, and the relative expression levels were calculated using the ${ }^{\Delta \Delta} \mathrm{Ct}$ method.

\section{Immunodetection of ATG8 using a tyramide signal amplification (TSA) assay}

A tyramide signal amplification (TSA) technique was used to assess the localization of ATG8 protein due to its high level of sensitivity. The TSA technique is approximately $1,000 \times$ more sensitive than the standard protocol for immunolocalization.

Pieces of fine roots and leaves were fixed in $2 \%(\mathrm{v} / \mathrm{v})$ glutaraldehyde ( $\mathrm{pH}$ 6.8; Polysciences, Warrington, USA) and 2\% (v/v) formaldehyde (pH 6.8; Polysciences, Warrington, USA) for $12 \mathrm{~h}$ and then rinsed three times in 1xPBS (Sigma) buffer. Immunolocalization in leaf samples utilized $32 \mu \mathrm{m}$ thick sections, which were obtained using a Leica VT $1200 S$ (Leica Biosystems, Nussloch, Germany) vibratome. Fine root samples were dehydrated in a graded ethanol series (10-100\%) and then infiltrated and embedded in Paraplast Extra (melting point $-57.8^{\circ} \mathrm{C}$; Sigma, St Louis, MO, USA). Fine root sections $(20 \mu \mathrm{m})$ were obtained using a Leica RM2265 (Leica Biosystems, Nussloch, Germany) microtome.

For immunolocalization, the material was incubated in $3 \%$ hydrogen peroxide solution for $1 \mathrm{~h}$ at RT to quench endogenous peroxidase activity. Subsequently, the material was rinsed three times in 0,01 M PBS buffer and blocked with $2 \%$ bovine serum albumin (BSA, Sigma) for 20 min. A primary ATG8 rabbit antibody (Agrisera) was used for immunolocalization of ATG8 proteins. The primary antibody was diluted 1:1000 in 0.2\% BSA (Sigma) and the sectioned material was incubated with the primary antibody at $6{ }^{\circ} \mathrm{C}$ overnight. The material was rinsed five times in PBS buffer and then incubated with poly-HRP-conjugated secondary antibody (Thermo Fisher Scientific Inc., USA, attached to TSA Super Boost kit) for $1 \mathrm{~h}$ at $36^{\circ} \mathrm{C}$. The antibodies were rinsed from the samples five times with PBS and then the samples were exposed to a working solution of tyramide for $8 \mathrm{~min}$ at RT. The working solution of tyramide was prepared according to the manufacturer's directions (Thermo Fisher Scientific Inc., USA). The reactions were arrested by the addition of $100 \mu \mathrm{l}$ of a stop reagent (Thermo Fisher Scientific Inc., USA). After rinsing in PBS buffer, the sectioned samples were mounted in Prolong Gold (Life Technologies). Results of the immunolocalization assay were recorded with a Leica TCS SP5 confocal microscope (Leica Biosystems, Nussloch, Germany). Negative control reactions produced an undetectably low signal compared with the standard reactions (Additional file 1, Figure S1).

\section{Statistical analysis}

Statistical analyses (ANOVA and Tukey's test) were performed using Statistica 12.0 software (StatSoft Poland Inc., Tulsa, OH, USA).

\section{Additional file}

Additional file 1: Figure S1. Comparison of ATG8 immunolocalization reactions with a negative control. Figure. $1 a, b-$ The localization of ATG8 in senescence leaf. Fig. 1c, d-The negative control reaction performed omiting the primary antibody. (TIF $42774 \mathrm{~kb}$ )

\section{Abbreviations}

ATG: Autophagy related genes; BSA: Bovine serum albumin; GFP: green fluorescent protein; LC: Control (green leaves); LS1: First stage of senescence (yellowing leaves); LS2: Second stage of senescence (yellow leaves); PBS: Phosphate-buffered saline; PE: Phosphatidylethanolamine; RC: Control (white fine roots); RCB: Rubisco-containing bodies; RFP: Red fluorescent protein; RS1: First stage of senescence (brown fine roots); RS2: Second stage of senescence (dark brown or black fine roots); RT: Room temperature; TSA: Tyramide signal amplification; WT: Wild type

\section{Acknowledgements}

The authors thank J. Mucha from Institute of Dendrology, Polish Academy of Science for allowing the use of a confocal microscope and for technical support.

\section{Funding}

This work was supported by the grant no. 2012/07/E/NZ9/00194 to ABZ from the National Science Centre, Poland and by the grant no. 2016/23/N/ NZ3/00073 to NW from the National Science Centre, Poland.

\section{Availability of data and materials}

The datasets used and/or analysed during the current study are available from the corresponding author on reasonable request. 


\section{Authors' contributions}

NW collected material and performed the analyses with contributions from KMS, EK, AZN, AMJ; ABZ conceived the original concept and research plan, designed the experiments and oversaw the study; NW and ABZ analyzed the data, NW wrote the first draft of the manuscript with critical comments and supervision provided by ABZ; all authors discussed the results, read, and approved the final version of the manuscript.

\section{Ethics approval and consent to participate}

This article does not contain any studies with human participants or animals performed by any of the authors. The ethics approval is unnecessary for our study.

\section{Consent for publication}

All authors read the manuscript and approved its final version.

\section{Competing interests}

Trade names or commercial products mentioned in this publication are only to provide specific information and do not imply any recommendation or endorsement by the authors.

\section{Publisher's Note}

Springer Nature remains neutral with regard to jurisdictional claims in published maps and institutional affiliations.

\section{Author details}

'Department of General Botany, Institute of Experimental Biology, Faculty of Biology, Adam Mickiewicz University, Umultowska 89, 61-614 Poznań, Poland. ${ }^{2}$ Institute of Dendrology, Polish Academy of Sciences, Parkowa 5, 62-035 Kórnik, Poland. ${ }^{3}$ Department of Virusology and Bacteriology, Institute of Plant Protection, Węgorka 20, 60-318 Poznań, Poland.

Received: 13 May 2018 Accepted: 24 September 2018

\section{Published online: 29 October 2018}

\section{References}

1. Lim PO, Kim HJ, Nam HG. Leaf senescence. Annu Rev Plant Biol. 2007;58: 115-36.

2. Wojciechowska N, Sobieszczuk-Nowicka E, Bagniewska-Zadworna A. Plant organ senescence - regulation by manifold pathways. Plant Biol. 2018;20: 167-81.

3. Hollmann J, Gregersen PL, Krupinska K. Identification of predominant genes involved in regulation and execution of senescence-associated nitrogen remobilization in flag leaves of field grown barley. J Exp Bot. 2014;65:3963-73.

4. Della Mea M, De Filippis F, Genovesi V, Serafini Fracassini D, Del Duca S. The acropetal wave of developmental cell death of tobacco corolla is preceded by activation of transglutaminase in different cell compartments. Plant Physiol. 2007;144:1211-22.

5. Lam E. Controlled cell death, plant survival and development. Nat Rev Mol Cell Biol. 2004;5:305-15.

6. Liu J, Wu YH, Yang JJ, Liu YD, Shen FF. Protein degradation and nitrogen remobilization during leaf senescence. J Plant Biol. 2008;51:11-9.

7. Masclaux-Daubresse $C$, Chen $Q$, Havé $M$. Regulation of nutrient recycling via autophagy. Curr Opin Plant Biol. 2017;39:8-17.

8. Rogers HJ. Programmed cell death in floral organs: how and why do flowers die? Ann Bot. 2006:97:309-15.

9. Guiboileau A, Yoshimoto K, Soulay F, Bataillé MP, Avice JC, MasclauxDaubresse C. Autophagy machinery controls nitrogen remobilization at the whole-plant level under both limiting and ample nitrate conditions in Arabidopsis. New Phytol. 2012:194:732-40.

10. Guiboileau A, Avila-Ospina L, Yoshimoto K, Soulay F, Azzopardi M, Marmagne A, Lothier J, Masclaux-Daubresse C. Physiological and metabolic consequences of autophagy deficiency for the management of nitrogen and protein resources in Arabidopsis leaves depending on nitrate availability. New Phytol. 2013;199:683-94.

11. Li F, Chung T, Pennington JG, Federico ML, Kaeppler HF, Kaeppler SH, Otegui MS, Vierstra RD. Autophagic recycling plays a central role in maize nitrogen remobilization. Plant Cell. 2015;27:1389-408.

12. Shibuya K, Niki T, Ichimura K. Pollination induces autophagy in petunia petals via ethylene. J Exp Bot. 2013;64:1111-20.

13. Nakatogawa $H$, Suzuki $K$, Kamada $Y$, Ohsumi $Y$. Dynamics and diversity in autophagy mechanisms: lessons from yeast. Nat Rev Mol Cell Biol. 2009;10:458-67.
14. Kim SH, Kwon C, Lee JH, Chung T. Genes for plant autophagy: functions and interactions. Mol Cells. 2012;34:413-23.

15. Klionsky DJ, Abdalla FC, Abeliovich H, Abraham RT, Acevedo-Arozena A, Adeli K, Agholme L, Agnello M, Agostinis P, Aguirre-Ghiso JA, et al. Guidelines for the use and interpretation of assays for monitoring autophagy (3rd edition). Autophagy. 2016:12:1-222.

16. Kurusu T, Koyano T, Hanamata S, Kubo T, Noguchi Y, Yagi C, Nagata N, Yamamoto T, Ohnishi T, Okazaki Y, Kitahata N, Ando D, Ishikawa M, Wada S, Miyao A, Hirochika H, Shimada H, Makino A, Saito K, Ishida H, Kinoshita T, Kurata N, Kuchitsu K. OsATG7 is required for autophagy-dependent lipid metabolism in rice postmeiotic anther development. Autophagy. 2014;10: 878-88.

17. Kwon SI, Cho HJ, Jung JH, Yoshimoto K, Shirasu K, Park OK. The Rab GTPase RabG3b functions in autophagy and contributes to tracheary element differentiation in Arabidopsis. Plant J. 2010;64:151-64.

18. Sbrana FV, Cortini M, Avnet S, Perut F, Columbaro M, De Milito A, Baldini N. The role of autophagy in the maintenance of stemness and differentiation of mesenchymal stem cells. Stem Cell Rev. 2016;12:621-33.

19. Lai Z, Wang F, Zheng Z, Fan B, Chen Z. A critical role of autophagy in plant resistance to necrotrophic fungal pathogens. Plant J. 2011;66:953-68.

20. Lenz HD, Haller E, Melzer E, Kober K, Wurster K, Stahl M, Bassham DC, Vierstra RD, Parker JE, Bautor J, Molina A, Escudero V, Shindo T, van der Hoorn RA, Gust AA, Nürnberger T. Autophagy differentially controls plant basal immunity to biotrophic and necrotrophic pathogens. Plant J. 2011;66:818-30.

21. Liu Y, Schiff M, Czymmek K, Tallóczy Z, Levine B, Dinesh-Kumar SP. Autophagy regulates programmed cell death during the plant innate immune response. Cell. 2005;121:567-77.

22. Wang $Y$, Nishimura MT, Zhao T, Tang D. ATG2, an autophagy-related protein, negatively affects powdery mildew resistance and mildew-induced cell death in Arabidopsis. Plant J. 2011:68:74-87.

23. Wang Y, Wu Y, Tang D. The autophagy gene, ATG18a, plays a negative role in powdery mildew resistance and mildew-induced cell death in Arabidopsis. Plant Signal Behav. 2011;6:1408-10.

24. Rose TL, Bonneau L, Der C, Marty-Mazars D, Marty F. Starvation-induced expression of autophagy-related genes in Arabidopsis. Biol Cell. 2006;98:53-67.

25. Slavikova S, Ufaz S, Avin-Wittenberg T, Levanony H, Galili G. An autophagyassociated Atg8 protein is involved in the responses of Arabidopsis seedlings to hormonal controls and abiotic stresses. J Exp Bot. 2008:59:4029-43.

26. Xiong Y, Contento AL, Nguyen PQ, Bassham DC. Degradation of oxidized proteins by autophagy during oxidative stress in Arabidopsis. Plant Physiol. 2007:143:291-9.

27. Xiong $\mathrm{Y}$, Contento AL, Bassham DC. Disruption of autophagy results in constitutive oxidative stress in Arabidopsis. Autophagy. 2007:3:257-8.

28. Yoshimoto K, Jikumaru $Y$, Kamiya $Y$, Kusano M, Consonni C, Panstruga $R$ Ohsumi Y, Shirasu K. Autophagy negatively regulates cell death by controlling NPR1-dependent salicylic acid signaling during senescence and the innate immune response in Arabidopsis. Plant Cell. 2009:21:2914-27.

29. Bagniewska-Zadworna A, Stelmasik A, Minicka J. From birth to death — Populus trichocarpa fibrous roots functional anatomy. Biol Plant. 2014:58:551-60.

30. van Doorn WG, Woltering EJ. Senescence and programmed cell death: substance or semantics? J Exp Bot. 2004:55:2147-53.

31. van Doorn WG, Woltering EJ. Many ways to exit? Cell death categories in plants. Trends Plant Sci. 2005:10:117-22.

32. Wittenbach VA, Lin W, Hebert RR. Vacuolar localization of proteases and degradation of chloroplasts in mesophyll protoplasts from senescing primary wheat leaves. Plant Physiol. 1982;69:98-102.

33. Matile P, Winkenbach F. Function of lysosomes and lysosomal enzymes in the senescing corolla of the morning glory (Ipomoea purpurea). J Exp Bot. 1971:22:759-71.

34. Smith MT, Saks Y, van Staden J. Ultrastructural changes in the petals of senescing flowers of Dianthus caryophyllus L. Ann Bot. 1992;69:277-85.

35. Thumm M, Egner $R$, Koch $B$, Schlumpberger M, Straub M, Veenhuis M, Wolf $\mathrm{DH}$. Isolation of autophagocytosis mutants of Saccharomyces cerevisiae. FEBS Lett. 1994:349:275-80.

36. Doelling JH, Walker JM, Friedman EM, Thompson AR, Vierstra RD. The APG8/ 12-activating enzyme APG7 is required for proper nutrient recycling and senescence in Arabidopsis thaliana. J Biol Chem. 2002;277:33105-14.

37. Hanaoka H, Noda T, Shirano Y, Kato T, Hayashi H, Shibata D, Tabata S, Ohsumi $Y$. Leaf senescence and starvation-induced chlorosis are accelerated by the disruption of an Arabidopsis autophagy gene. Plant Physiol. 2002;129:1181-93. 
38. Xiong $Y$, Contento AL, Bassham DC. AtATG18a is required for the formation of autophagosomes during nutrient stress and senescence in Arabidopsis thaliana. Plant J. 2005;42:535-46.

39. Xia K, Liu T, Ouyang J, Wang R, Fan T, Zhang M. Genome-wide identification, classification, and expression analysis of autophagy-associated gene homologues in rice (Oryza sativa L.). DNA Res Int J Rapid Publ Rep Genes Genomes. 2011;18:363-77.

40. Chung T, Suttangkakul A, Vierstra RD. The ATG autophagic conjugation system in maize: ATG transcripts and abundance of the ATG8-lipid adduct are regulated by development and nutrient availability. Plant Physiol. 2009; 149:220-34.

41. Avila-Ospina L, Moison M, Yoshimoto K, Masclaux-Daubresse C. Autophagy, plant senescence, and nutrient recycling. J Exp Bot. 2014;65:3799-811.

42. van der Graaff E, Schwacke R, Schneider A, Desimone M, Flügge UI, Kunze R. Transcription analysis of Arabidopsis membrane transporters and hormone pathways during developmental and induced leaf senescence. Plant Physiol. 2006;141:776-92.

43. Shibuya K, Shimizu K, Yamada T, Ichimura K. Expression of autophagyassociated ATG8 genes during petal senescence in Japanese morning glory. J Jpn Soc Hortic Sci. 2011;80:89-95.

44. Sobieszczuk-Nowicka E, Wrzesiński T, Bagniewska-Zadworna A, Kubala S, Rucińska-Sobkowiak R, Polcyn W, Misztal L, Mattoo AK. Physio-genetic dissection of dark-induced leaf senescence and timing its reversal in barley. Plant Physiol. 2018;178:654-71.

45. Yanai RD, Eissenstat DM. Coping with herbivores and pathogens: a model of optimal root turnover. Funct Ecol. 2002;16:865-9.

46. McCormack M, Dickie IA, Eissenstat DM, Fahey TJ, Fernandez CW, Guo D, Helmisaari HS, Hobbie EA, Iversen CM, Jackson RB, Leppälammi-Kujansuu J, Norby RJ, Phillips RP, Pregitzer KS, Pritchard SG, Rewald B, Zadworny M. Redefining fine roots improves understanding of below-ground contributions to terrestrial biosphere processes. New Phytol. 2015;207:505-18.

47. Valenzuela-Estrada LR, Vera-Caraballo V, Ruth LE, Eissenstat DM. Roo anatomy, morphology, and longevity among root orders in Vaccinium corymbosum (Ericaceae). Am J Bot. 2008;95:1506-14.

48. Brassard BW, Chen HYH, Bergeron Y. Influence of environmental variability on root dynamics in northern forests. Crit Rev Plant Sci. 2009:28:179-97.

49. Gill RA, Jackson RB. Global patterns of root turnover for terrestrial ecosystems. New Phytol. 2008;147:13-31.

50. Comas LH, Eissenstat DM, Lakso AN. Assessing root death and root system dynamics in a study of grape canopy pruning. New Phytol. 2000;147:171-8.

51. Otegui MS, Noh YS, Martínez DE, Vila Petroff MG, Staehelin LA, Amasino RM, Guiamet JJ. Senescence-associated vacuoles with intense proteolytic activity develop in leaves of Arabidopsis and soybean. Plant J. 2005;41:831-44.

52. López-Fernández MP, Burrieza HP, Rizzo AJ, Martínez-Tosar LJ, Maldonado S. Cellular and molecular aspects of quinoa leaf senescence. Plant Sci. 2015; 238:178-87.

53. Lin M, Pang C, Fan S, Song M, Wei H, Yu S. Global analysis of the Gossypium hirsutum L. transcriptome during leaf senescence by RNA-Seq. BMC Plant Biol. 2015;15:43.

54. Biswal B. Carotenoid catabolism during leaf senescence and its control by light. J Photochem Photobiol B. 1995;30:3-13.

55. Shibuya K, Shimizu K, Niki T, Ichimura K. Identification of a NAC transcription factor, Ephemeral1, that controls petal senescence in Japanese morning glory. Plant J. 2014;79:1044-51.

56. Yamada T, Takatsu Y, Kasumi M, Ichimura K, van Doorn WG. Nuclear fragmentation and DNA degradation during programmed cell death in petals of morning glory Ipomoea nil. Planta. 2006;224:1279-90.

57. Macnish AJ, Jiang CZ, Negre-Zakharov F, Reid MS. Physiological and molecular changes during opening and senescence of Nicotiana mutabilis flowers. Plant Sci. 2010;179:267-72.

58. Yamada T, Ichimura K, van Doorn WG. (2006b) DNA degradation and nuclear degeneration during programmed cell death in petals of Antirrhinum, Argyranthemum, and Petunia. J Exp Bot. 2006;57:3543-52.

59. Langston BJ, Bai S, Jones ML. Increases in DNA fragmentation and induction of a senescence-specific nuclease are delayed during corolla senescence in ethylene-insensitive (etr1-1) transgenic petunias. J Exp Bot. 2005;56:15-23.

60. Kim JH, Okubo H, Fujieda K, Uemoto S. Changes of petal colors during senescence in Hibiscus syriacus. J Fac Agric - Kyushu Univ Jpn. 1989;33:259-65.

61. Keech O, Pesquet E, Gutierrez L, Ahad A, Bellini C, Smith SM, Gardeström P. Leaf senescence is accompanied by an early disruption of the microtubule network in Arabidopsis. Plant Physiol. 2010;154:1710-20.
62. van Doorn WG, Papini A. Ultrastructure of autophagy in plant cells: a review. Autophagy. 2013;9:1922-36.

63. Ishida H, Yoshimoto K, Izumi M, Reisen D, Yano Y, Makino A, Ohsumi Y, Hanson MR, Mae T. Mobilization of rubisco and stroma-localized fluorescent proteins of chloroplasts to the vacuole by an ATG gene-dependent autophagic process. Plant Physiol. 2008;148:142-55.

64. Ishida H, Izumi M, Wada S, Makino A. Roles of autophagy in chloroplast recycling. Biochim Biophys Acta. 2014;1837:512-21.

65. Li F, Vierstra RD. Autophagy: a multifaceted intracellular system for bulk and selective recycling. Trends Plant Sci. 2012;17:526-37.

66. Yoshimoto K. Beginning to understand autophagy, an intracellular selfdegradation system in plants. Plant Cell Physiol. 2012;53:1355-65.

67. Bagniewska-Zadworna A, Byczyk J, Eissenstat DM, Oleksyn J, Zadworny M. Avoiding transport bottlenecks in an expanding root system: xylem vessel development in fibrous and pioneer roots under field conditions. Am J Bot. 2012;99:1417-26.

68. van Doorn WG, Woltering EJ. Physiology and molecular biology of petal senescence. J Exp Bot. 2008;59:453-80.

69. Ono Y, Wada S, Izumi M, Makino A, Ishida H. Evidence for contribution of autophagy to rubisco degradation during leaf senescence in Arabidopsis thaliana. Plant Cell Environ. 2013;36:1147-59.

70. Ohsumi Y. Molecular dissection of autophagy: two ubiquitin-like systems. Nat Rev Mol Cell Biol. 2001;2:211-6.

71. Xie Z, Nair U, Klionsky DJ. Atg8 controls phagophore expansion during autophagosome formation. Mol Biol Cell. 2008;19:3290-8.

72. Thompson AR, Doelling JH, Suttangkakul A, Vierstra RD. Autophagic nutrient recycling in Arabidopsis directed by the ATG8 and ATG12 conjugation pathways. Plant Physiol. 2005;138:2097-110.

73. Wada S, Ishida H. Chloroplasts autophagy during senescence of individually darkened leaves. Plant Signal Behav. 2009;4:565-7.

74. Ishida H, Yoshimoto K. Chloroplasts are partially mobilized to the vacuole by autophagy. Autophagy. 2008:4:961-2.

75. Uzelac B, Janošević D, Simonović A, Motyka V, Dobrev PI, Budimir S. Characterization of natural leaf senescence in tobacco (Nicotiana tabacum) plants grown in vitro. Protoplasma. 2016;253:259-75.

76. Wells CE, Eissenstat DM. Marked differences in survivorship among apple roots of different diameters. Ecology. 2001:82:882-92.

77. Xia M, Guo D, Pregitzer KS. Ephemeral root modules in Fraxinus mandshurica. New Phytol. 2010;188:1065-74.

78. McCormack LM, Adams TS, Smithwick EAH, Eissenstat DM. Predicting fine root lifespan from plant functional traits in temperate trees. New Phytol. 2012;195:823-31.

79. Zenkteler E, Bagniewska-Zadworna A. Ultrastructural changes in rhizome parenchyma of Polypodium vulgare during dehydration with or without abscisic acid pretreatment. Biol Plant. 2005;49:209-14.

80. Szuba A, Wojakowska A, Lorenc-Plucińska G. An optimized method to extract poplar leaf proteins for two-dimensional gel electrophoresis guided by analysis of polysaccharides and phenolic compounds. Electrophoresis. 2013;34:3234-43.

81. Kalemba EM, Litkowiec M. Functional characterization of a dehydrin protein from Fagus sylvatica seeds using experimental and in silico approaches. Plant Physiol Biochem. 2015;97:246-54.

82. Bagniewska-Zadworna A, Stelmasik A. Root heterogeneity and developmental stage determine the pattern of cellulose synthase and cinnamyl alcohol dehydrogenase gene expression profiles during xylogenesis in Populus trichocarpa (Torr. Et gray). Int J Plant Sci. 2015;176: 458-67.

Ready to submit your research? Choose BMC and benefit from:

- fast, convenient online submission

- thorough peer review by experienced researchers in your field

- rapid publication on acceptance

- support for research data, including large and complex data types

- gold Open Access which fosters wider collaboration and increased citations

- maximum visibility for your research: over $100 \mathrm{M}$ website views per year

At $\mathrm{BMC}$, research is always in progress.

Learn more biomedcentral.com/submission 